\title{
Does one size fit all? An analysis of portfolio allocation in the Brazilian multiparty presidential system
}

\author{
Pedro Lucas de Moura Palotti ${ }^{1}$ \\ Pedro Luiz Costa Cavalcante ${ }^{2}$
}

\begin{abstract}
Presidents face a dilemma of whom to appoint for cabinet positions. They need to secure legislative support for their government and at the same time achieve their goals in terms of public policy. This work analyzes the portfolio allocation of Brazilian presidents in Brazil's multiparty system. This study tests some hypotheses using multinomial logistic regression to identify appointment strategies adopted by the presidents in four different governmental sectors from 1990 to 2016 . To do so, first, we create an index of ministerial politicization (IMP) and aggregate the ministries in these four sections, employing cluster analysis. The results show that appointments to the core positions in government tend to be less politicized. Moreover, the president's personal nominations were greater in the presidential units that carry out the political coordination and typical functions of the State.

Keywords: Brazilian multiparty presidential system; cabinet ministers appointment; government coalition management; Brazil
\end{abstract}

\section{Introduction}

In multiparty presidential systems, it is common for the president's party to have minority in parliament. In this sense, the president appoints ministers from other political parties to become part of a coalition government. This is one of the most powerful mechanisms for the president to secure legislative support, which is critical to advancing the president's agenda during the administration. This has been the case of Brazil since the reestablishment of elected governments in 1990. None of the parties of the coalition achieved 20\% representation in the lower chamber (Câmara dos Deputados).

Studies on coalition presidentialism (presidencialismo de coalizão) in Brazil have focused on the format of the majority government and the regional and political representation of the ministries (Meneguello, 1996). Scholars have also investigated minister profiles, professional trajectories, and primarily the proportionality of the

\footnotetext{
${ }^{1}$ Escola Nacional de Administração Pública, Brasília (DF), Brasil. E-mail: <pedro.palotti@enap.gov.br>. Orcid: <https://orcid.org/0000-0002-9071-9726>.

2 Instituto de Pesquisa Econômica Aplicada (Ipea), Brasília (DF), Brasil.

E-mail: <pedro.cavalcante@ipea.gov.br>. Orcid: <https://orcid.org/0000-0001-7635-695X>.
} 
ministers and secretariats in relation to the parties' distribution of seats in the lower chamber (Amorim Neto, 2000). For this reason, the presidential rationale shares some of the top positions as a way to guarantee parties' support, which is in line with the literature's perception that this strategy provides political benefits (Lewis, 2009).

Recently, the distribution of cabinet posts has been considered under different perspectives. These posts differ according to budgetary resources, free appointment and dismissal, in addition to the importance in terms of regulatory capacity and control of bureaucratic agencies (Mauerberg Jr., 2016) or sharing of government agenda (Batista, 2016). Politicization is measured not only by the proportionality of ministries in relation to the political division in Congress. It is also central to understanding how the ministerial resources are distributed among the key coalition partners in different policies and government functions.

Few studies have addressed the presidential dilemma regarding cabinet appointments in Brazil. What ministries does the chief of the executive branch delegate to allied parties and which ones does the president entrust to his or her own party or to nonparty affiliated professionals? Do the nominees vary according to the level of political attractiveness of the ministries?

To address these questions, this paper uses a comprehensive and original database of cabinet appointments that covers the recent democratic presidential terms in Brazil from 1990 to 2016. It employs the index of ministerial politicization (IMP) and the indicators of ministerial political attractiveness proposed by Mauerberg Jr. (2016) to test our hypotheses regarding the types of appointments in four different areas of ministry: a) core; b) policy delivery; c) political coordination and State functions; and d) presidential office. The explanation for the IMP and the division of ministries according to political attractiveness are described in greater detail in the paper's appendix.

Based on that, a multinomial logistic regression was used in order to identify appointment strategies adopted by presidents. The models' results show that ministers' features affect their appointments in different ways. Primarily, the president's party peers, those supporting the coalition, or ministers without partisan affiliation, as well as their level of politicization, are important dimensions of portfolio allocation in Brazil. In this sense, the minister profile changes according to the policy area. In fact, these variables depict delegation's inherited costs between the Principal (the president and, in most cases, party leaders) and its Agents (State ministers).

In addition to this introduction, the paper includes six sections. The next section discusses the context of coalition presidentialism in Brazil, followed by a review of the literature on cabinet unit salience and the methodological strategies used to measure it. Then, analysis is presented about ministerial assignments based on the political attractiveness of the ministries, and the research hypotheses are debated. The data and methods, as well as the descriptive analysis, constitute the fifth section. Lastly, the outputs of the multinomial logistic regression are presented followed by some final remarks. 


\section{Coalition presidentialism in Brazil}

The appointment of government staff is well-known as one of the main assets available to the chief of government to produce favorable legislative decisions and enable them to reach their preferences regarding the public policy agenda. Selecting members to appoint to a ministerial cabinet demands deliberated calculations in a multifaceted environment. Aspects related to the president or the prime minister's party structure, the political and social support groups, and regional, ethnic, and religious issues, as well as variables concerning the individual capacities of the ministerial candidates, make the decisions multivariate, dynamic, and highly complex.

The literature emphasizes three main strategies ${ }^{3}$ for portfolio allocation available to the chief of the executive branch, which are: 1) the need of proportionality of party representation in the legislative branch; 2) the need to control top policymaking officials; and 3 ) the need to represent politically different groups in society. Despite some efforts of Brazilian scholars to cover the latter two strategies (Figueiredo, 2007; D'Araujo and Lameirão, 2009; D'Araujo, 2014), the bulk of the studies on the Brazilian case has focused on the first strategy, considering the context of coalition presidentialism (Abranches, 1988; Figueiredo e Limongi, 1999; Amorim Neto, 2007).

In Brazil, presidents have powerful institutional prerogatives, such as issuing executive orders (called medidas provisórias), which give them an opportunity to initiate legislation in a broad variety of issues and is particularly important resource for changing the status quo to a new equilibrium acceptable to other political actors and closer to presidential preferences (Figueiredo and Limongi, 2007). They also can decide discretionarily how to allocate public expenditures and how public policy formulation is centralized in the federal government (Arretche, 2009; Abrucio and Costa, 1999; Machado and Palotti, 2015).

Although the chief of government is also powerful, in the context of a coalition presidentialism the political negotiations regarding the division of power among the coalition parties are also important. The president and the political parties are principals, so they are the main actors who decide to appoint ministers-agents who act on their behalf. This is the typical agency theory relationship.

The fundamental dilemma of agency theory is that both the agent and the principal have their own utility functions and try to maximize them. A payoff or reward is given to the agent depending on his or her performance. The principal determines the reward depending on information regarding the agent's achievements (Ross, 1973).

Moreover, the president must consider the complex dynamics preference of the coalition parties when assigning cabinet positions in order to increase his or her political

\footnotetext{
3 The deliberate process of selecting and appointing ministers in a context of multiple actors and political arenas is closer to the concept of strategy. Strategies are deliberate actions that include mainly incentives, cost-benefit calculations, and other actors' behaviors, among other factors.
} 
support. According to Altman (2000), rational-choice theorists often argue that political parties' main preferences are for electoral votes, cabinet positions, and public policies-or a combination of these three purposes. Limongi and Figueiredo (2009) similarly argue that the participation of multiple parties in government occurs in order to garner political benefits such as appointing positions to civil servants, allocating budget resources, and defining the ministries' guidelines. In this regard, empirical evidence indicates, first, that coalitions are no exception in presidential systems in which the executive branch has legislative powers ${ }^{4}$.

So, in the context of coalition presidentialism, ministers are agents who in general answer to two principals: political parties and the president, as shown in Figure 1:

Figure 1

Agency-principal relationships

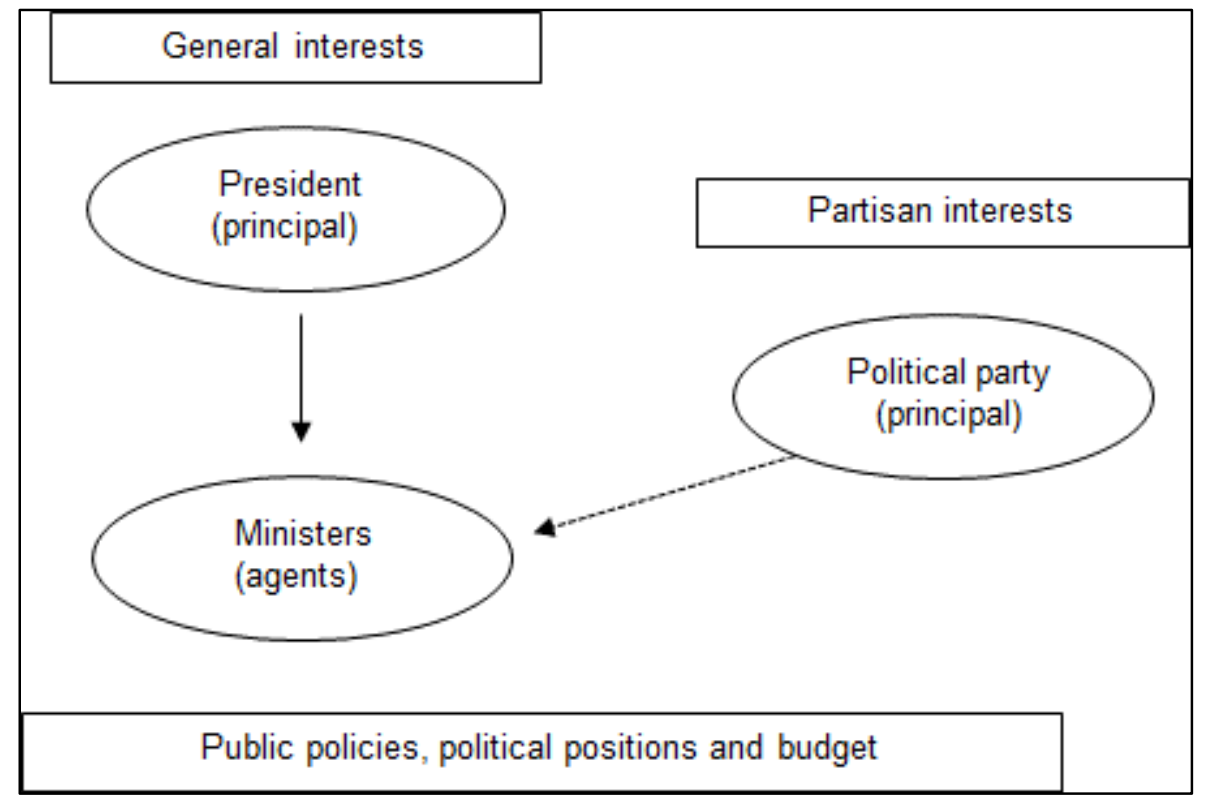

Source: Elaborated by the authors.

In general, even when the minister comes from the president's party, it is assumed that these principals have different interests (Martínez-Gallardo and Schleiter, 2014) ${ }^{5}$. The president aims to attain majority support at the national level, while parties, even the president's own, target their party interests in specific geographic regions or their constituency. This configuration may imply a distinct dynamic between appointees linked

\footnotetext{
${ }^{4}$ Figueiredo, Canello and Vieira (2012) show that almost 75\% of the cabinets formed between 1979 and 2011 in Latin America were coalitions, even though a significant percentage of them were minority coalitions (about 30\%).

5 For a detailed discussion about the main challenges of multiple principals, see Dixit (1997).
} 
to political parties or acting as delegates of said parties (with multiple representatives) of those without party affiliation (with the president as sole agent), regardless of technical knowledge, managerial experience, or educational background. The resources mobilized by the ministers involve policy implementation, appointment of commissioned positions, and the execution of budgetary resources.

As the costs of monitoring agents, directly or indirectly, are high, the decision of whom to appoint and where to allocate them is crucial. In order to deal with this context, presidents use two complementary delegation strategies: appointing ministers without political affiliation, mainly to guarantee direct influence over the portfolio (Amorim Neto and Samuels, 2010; Martínez-Gallardo and Schleiter, 2014); or restricting some areas of government to his or her own party or to those ministers without political affiliation ${ }^{6}$.

A coalitional paradigm has emerged in Brazil in the last decades, as shown in Table 1. Collor, the first elected president after the 1988 Constitution, ruled with a minority coalition, although his term was interrupted by his impeachment in 1992. Apart from this example, only two coalitions, one at the end of Cardoso's second term and another at the beginning Da Silva's first term, were temporarilly minority. Gradually, the number of allied parties and the range of the ideological spectrum between left and right within the same presidential term expanded, as illustrated by the growth in the median of coalition parties' ideological heterogeneity (Zucco, 2014).

Collor's administration initiates Brazil's historical experience with 3.25 parties, on average, in his coalition and a median of the parties' heterogeneity of 0.79 , on a scale ranging from 1 (left) to 10 (right). That is, few relatively homogeneous parties were selected according to their ideological point of view. Franco and Cardoso's administrations aggregate a higher average of parties-about four-and extend the ideological heterogeneity beyond two. On the other hand, Da Silva and Rousseff's terms raised the maximum number of parties in the coalitions, more than seven, with ideological heterogeneity, reaching 4 points, including parties from across the (leftist and rightist) spectrum.

\footnotetext{
6 The main arguments about government formation in terms of proportionality and portfolio allocation will be discussed in the next section.
} 
Table 1

Presidential terms and coalition strategies (1990-2016)

\begin{tabular}{|l|c|c|c|c|c|c|c|c|}
\hline President & $\begin{array}{c}\text { Party } \\
\text { affiliation }\end{array}$ & Inauguration & End of term & $\begin{array}{c}\text { Number } \\
\text { of days }\end{array}$ & $\begin{array}{c}\text { Number of } \\
\text { coalitions }\end{array}$ & $\begin{array}{c}\text { Aype of } \\
\text { Coalitions }\end{array}$ & $\begin{array}{c}\text { Average } \\
\text { number of } \\
\text { coalition } \\
\text { parties }\end{array}$ & $\begin{array}{c}\text { Median of the } \\
\text { coalitions' } \\
\text { heterogeneity }\end{array}$ \\
\hline Collor & PRN & $03 / 15 / 1990$ & $10 / 02 / 1992 *$ & 932 & 4 & Minority & 3.25 & 0.79 \\
\hline $\begin{array}{l}\text { Itamar } \\
\text { Franco }\end{array}$ & $\begin{array}{c}\text { Non party } \\
\text { affiliated }\end{array}$ & $10 / 02 / 1992$ & $01 / 01 / 1995$ & 821 & 3 & Majority & 4.67 & 2.78 \\
\hline Cardoso I & PSDB & $01 / 01 / 1995$ & $01 / 01 / 1999$ & 1461 & 2 & Majority & 4.50 & 2.29 \\
\hline Cardoso II & PSDB & $01 / 01 / 1999$ & $01 / 01 / 2003$ & 1461 & 2 & Mixed $^{9}$ & 3.50 & 1.97 \\
\hline Da Silva I & PT & $01 / 01 / 2003$ & $01 / 01 / 2007$ & 1461 & 5 & Mixed & 7.20 & 3.70 \\
\hline Da Silva II & PT & $01 / 01 / 2007$ & $01 / 01 / 2011$ & 1461 & 3 & Majority & 8.33 & 3.95 \\
\hline Rousseff I & PT & $01 / 01 / 2011$ & $01 / 01 / 2015$ & 1461 & 3 & Majority & 7.33 & 4.07 \\
\hline Rousseff II & PT & $01 / 01 / 2015$ & $12 / 05 / 2016 *$ & 497 & 2 & Majority & 10.00 & - \\
\hline
\end{tabular}

Source: Elaborated by the authors, from the Legislative Database of Cebrap, Figueiredo (2007) and Zucco (2014). Note: * Date on which the presidents were removed from government for judgment in impeachment proceedings.

Therefore, in the Brazilian case, the centrifugal institutional factors, which supposedly could generate greater division and control of political power, did not act as barriers to relatively long lasting and effective coalitions. However, as Batista (2014) argues, although allied, the coalition partners' positions in government are diverse and asymmetrical. Based on lawmaking and budget allocation during the Cardoso and Da Silva administrations, the author points out that coalition parties performed poorly in the approval of their own bills, unlike the ministers from the president's party. Meanwhile in terms of budget allocation, the cabinet as a whole seems to be more equal.

In sum, the presidential agenda powers-along with other centralizing aspects of the congressional framework and the constitutional prerogatives of the federal government-have created the conditions necessary to overcome decision paralysis problems during most of the recent democratic period. These elements help, to a certain extent, explain how presidents have dealt with the Brazilian institutional dilemma. They are precisely defined as the "center of gravity" of the political system (Amorim Neto, 2007). However, this does not explain everything, especially, because the president faces challenges not only managing the government, but also choosing those on whom he or she

\footnotetext{
7 The average number of coalition parties is calculated by dividing the total number of parties participating in the coalitions by the total number of coalitions by presidential term, without considering the average duration of each coalition, according to the initial proposal of Pereira, Bertholini and Raile (2016).

${ }^{8}$ The median coalition heterogeneity is calculated by the median of the highest ideological difference between parties along the left-right spectrum in each presidential coalition, without weighing the average duration of each coalition.

${ }^{9}$ After PFL (the major party allied in the coalition) left, the coalition formed in Fernando Henrique Cardoso's second term was a minority one (lasting from March to December 2002).

10 Lula's first coalition basically included allied parties during the electoral coalition, albeit a minority (from January 2003 to January 2004).
} 
must count. The next sections will analyze the complex appointment of ministers in the different political systems studied here, as well as provide some guidance regarding how to interpret these appointments in the last decades in Brazil.

\section{All ministers are equal, but some are more equal than others: main findings about portfolio allocation}

Studies on coalition formation and functioning are predominantly about parliamentary regimes-particularly in Western countries-focusing on the behavior of the core parties (the formateur) of the coalition and the other allied parties.

This kind of literature is based on the Gamson Law, which argues that there is proportionality between the seats controlled by a government coalition party in Congress and the number of ministries appointed in the cabinet. Based on this initial theoretical assumption, Warwick and Druckman (2001) support the idea that political scientists have mainly followed this assumption that divergence involves the causes of the possible disproportionality identified in the relationship between large parties and smaller parties in the coalition.

These authors point out two different explanatory approaches. The first argues that the party responsible for cabinet formation tends to be rewarded less compared to smaller parties in the coalition, normally overrepresented. The rationale is that the ruling coalition party would be willing to give up some ministerial posts to avoid negative reactions from small parties that might get upset about the dominance of the former (Warwick and Druckman, 2001). Emphasizing the agenda-setting of the ruling party, the second approach supports the idea that the ruling party has the advantage of proposing in advance the rewards for each partner. Since proposals must be judged together, most allied parties would tend to accept them, which would create incentives for the dominant party to distribute among the percentage of ministries proportionately larger than the others.

Although most of the empirical results, primarily in parliamentary systems, are in line with the premise of the first approach, quantitative measurement of rewards among the coalition parties has been carried out without consideration of qualitative aspects of the ministries. In this sense, the first question is: what dimensions can be highlighted to distinguish between more and less important ministries? To the extent that differences between the types of ministry appointed interfere in the proportionality of ministries among coalition partners, how do analysts, and, pragmatically, politicians involved in the negotiation process assess the ministerial portfolios?

As Dowding and Dumont (2009) point out, very little is known about how parties weigh the portfolios and which criteria they use to do so. This complex decision making may cover a variety of factors, such as policy salience according to the parties' background; new or traditional clientele interests; personal preferences of party leaders and others.

Case studies in parliamentary systems generally demonstrate the existence of 
priority ministries; however, they usually use less objective criteria. Berlinski et al. (2009) argue that the four major departments in the United Kingdom are: the prime minister's office, ministries of interior, foreign affairs, and economy. As Nikolenyi (2015) describes, in the Indian case, ministerial mobility at different moments in the country's political history has involved the dynamics observed in the four most important ministries: foreign relations, interior, defense, and finance. In the context of Italian parliamentarism, Verzichelli (2009) points out that the most wanted are the prime minister's office, politically visible ministries such as defense, justice, foreign affairs, and interior, and others with substantive resources, such as education, public works, and communications.

To address the challenge of understanding the ministerial portfolio assessment, Warwick and Druckman (2006) recommend first considering each party's preferences over each ministry. Despite the impossibility of subjective comparison between the partners, the authors argue that the best alternative for overcoming the merely quantitative consideration would be the comparison from an objective hierarchy among the ministries for a long period of time. Based on a survey of experts, Warwick and Druckman (2006) organize data on cabinet composition and the distribution of ministries among fourteen Western parliamentarian countries with coalition governments. Their conclusions confirm the proportionality of the distribution of ministries even when they introduce differences in the qualitative weight of these portfolios.

In presidential systems, little progress has been made on objective analysis of the qualitative allocation of ministries among coalition partners. The most consolidated theoretical advances can be seen in Amorim Neto's (2000) proposal for measuring the coalescence rate of presidential offices in Latin America. According to the author, coalescence comes down to the notion that "the greater the proportionality between the parties' ministerial quotas and their parliamentary seats, the more coalescing will be the [cabinet]" (Amorim Neto, 2000, p. 480). As is the case with coalitions in parliamentary systems, it is assumed that there will be coalescence in the cabinets formed by the presidents, as this is a crucial element of the agreement between a prime minister and allied parties and an element impacting on the degree of support and fidelity they secure in the legislative voting process.

The coalescence rate has the advantage of its replicability capacity for different political contexts, through a simple and independent calculation of complex assumptions. A disadvantage is that it neglects the salience of ministerial portfolios. In the presidentialist context, the measurement proposal must also take into account non-party affiliated appointments, more frequent in this case. Presidents often choose non-affiliated professionals to protect certain policy areas from being politicized in order to accomplish the administration's priority agenda (Martínez-Gallardo and Schleiter, 2014) or simply because of the lack of political attractiveness of some portfolios (Borges and Coelho, 2015).

Regarding the United States, Flores (2015) outlines that department appointments are also a relevant tool available to the president, particularly those close to the White 
House, in the following order: Secretary of State, Treasury, Defense, and Attorney General. This proximity is measured by the frequency with which these officials meet with the president. Together, these departments employ more than 300,000 public servants and are responsible for policies with a strong appeal to society and media (Flores, 2015).

In the same direction, Escobar-Lemmon and Taylor-Robinson's (2009) study includes the cases of the USA and four other Latin American countries. In their conclusion, they argue that ministers frequently alternate their service in presidential administrations. This phenomenon, characterized as a "revolving door", occurs in those ministries considered as the most prestigious and salient in these countries-foreign affairs, defense, and finance.

Only recently have political scientists in Brazil made efforts to understand this subject. Focused on the state level, Nunes (2013) proposes a weighted coalescence rate, taking into account the index composition, the proportion of investment in the public budget, and the amount of commissioned positions in the state secretariat. Jointly, these two dimensions should be compared with the total number of seats controlled by allied parties to identify the coalescence rate of each cabinet.

Batista (2016) conducts similar research for the federal government, gathering factual information that helps to distinguish between ministries according to their greater or lesser desirability among political parties. Three dimensions are observed: a) politicswhich indicates the participation of the Ministry in the legislative agenda of the executive branch, based on the authorship inscribed in the "explanatory statement" of the approved bills; b) positions-total of free commissioned posts, known as DAS; c) budget-total budget available for the portfolio. These variables were then aggregated employing factorial analysis to compare their degrees of political salience and, then, they were also contrasted to the total number of seats controlled by each party and the legislative support received. Empirical results indicate that the greater the proportionality of ministries distribution in relation to the parties' weight in the Chamber of Deputies, the greater the legislative support received. This scenario is confirmed by the index as a whole and for each of the dimensions analyzed.

Mauerberg Jr.'s (2016) research has the same goal, and it covers seven dimensions in order to depict the ministries' political attractiveness. Besides commissioned positions and total budget, the analysis includes the discretionary budget (resources transferred through agreements with state and local governments), total civil servants in the ministry, networking capacity (proportion of agencies attached to a ministry), the regulatory capacity over policies, and the average tenure of the ministers. The author weighs each of these dimensions of the political attractiveness index based on the opinions of congressmen and congresswomen. The dimensions that were weighted would be the most relevant to assess differences between ministries. Thus, this is a strategy for coping with a similar problem, which is the assumption that all these dimensions have equivalence in the evaluation of their attractiveness by political agents. 
Recent initiatives to explore the ministries salience in the Brazilian case have made progress. To begin with, they focus on objective measures, which tend to reduce the subjectivity of being strictly based on expert opinions, especially when it takes into account past moments. Secondly, the studies use data for every historical series and practically for the entire cabinet. Thirdly, they gather a comprehensive set of dimensions, although restricted to a particular case. And finally, at least for Mauerberg Jr.'s (2016) research, weighting based on the deputies' opinions, despite the subjectivity of this strategy, particularly for extinguished or merged ministries.

\section{Political attractiveness by sectors}

This section addresses the variety of political attractiveness inside the Brazilian executive branch in order to explore how the president appoints the ministries among members of his or her party, coalition allies, and non-partisan affiliated candidates. First, the proposed division is described; next, we present our hypotheses on ministerial appointments. Moreover, we are also interested in identifying possible variation on the degree of politicization among the ministry sectors.

The cabinet division adopted in this study uses five of the seven variables of political attractiveness gathered by Mauerberg Jr. (2016) without weighting. The dimensions are:

i. total budget;

ii. discretionary intergovernmental transfers from agreements;

iii. networking capacity (proportion of agencies attached to a ministry);

iv. total civil servants;

v. patronage (percentage of commissioned posts occupied by non-permanent civil servants).

Why would these variables represent political attractiveness? The answer to this question lies in the crucial difference between political parties and other kinds of social organizations. Pursuing political power, by electoral means in a democratic system, is the main goal of any political party, which separates parties from other types of organizations, such as labor unions, interest groups, and non-governmental organizations, among others. They all desire power in order to have their policymaking preferences addressed by the government, nevertheless, generally, only the political parties can reach the key appointments in the public sector through elections.

As mentioned, the literature shows that political parties' main preferences encompass electoral votes, administrative positions, and control of specific domains of public policy (Altman, 2000). Obviously, parties may have different interests in the area policy, for instance, Greens tend to be more inclined to environmental ministers, whereas socialist parties tend to prefer social areas. However, the biggest parties, are willing to 
focus on the most significant areas, because they want to maximize their political benefits, in terms of public visibility, credit claiming, and, above all, political power.

In this sense, we understand that these five variables, in the Brazilian case, are the ones that may represent, in quantitative and objective terms, the most desirable aspects of the ministers' political attractiveness. First, budget is an essential resource for almost any public policy implementation, which allows the ministry to effectively provide services and benefits, foster innovation in the area of policy, and, consequently, increase prestige and power (Niskanen, 1994). Intergovernmental transfers can also be seen as an asset of political power, primarily, those coming from federal agreements with subnational governments. Considering that most of them are highly financially dependent at the federal level (Arretche, 2009), the discretionary transfers by the ministers to mayoral or state governors' administrations can definitely be exchanged for the latter's support in forthcoming elections.

The third and fourth variables, networking capacity (the proportion of agencies attached to a ministry) and total of civil servants, indicate not only a wider range of activity, but also may foster more political visibility for a party. Lastly, the patronage dimension, measured by the percentage of commissioned posts occupied by non-permanent civil servants, may be interesting in order to include experts and trustful party members in strategic ministerial posts. This is important because, in the Brazilian federal government, the majority of the commissioned positions are mandatorily reserved to permanent civil servants (Cavalcante and Carvalho, 2017).

Employing cluster analysis, four different areas were obtained, all of them different after the variance analysis to a factor ( $F$ between 16.69 and 51.28 for the five dimensions, all at a level of significance of $0.1 \%$, the same results obtained for the corrections of Welch and Brown-Forsythe tests). The paper's appendix details the method used. Table 2 presents the differences between government areas based on the criteria of political attractiveness with the use of post hoc estimates to verify how groups differ. To facilitate visualization, non-standard values were used. The closer to 1 , the better the positioning of the group in the criterion observed. 
Table 2

Composition of each dimension by areas of political attractiveness

\begin{tabular}{|l|c|c|c|c|c|}
\hline $\begin{array}{l}\text { Areas of political } \\
\text { attractiveness }\end{array}$ & Total budget & Agreements & Networking & $\begin{array}{c}\text { Civil } \\
\text { servants }\end{array}$ & Patronage \\
\hline Core & $\mathbf{5 . 5 4}$ & 12.89 & $\mathbf{4 . 8 0}$ & $\mathbf{3 . 9 6}$ & $\mathbf{5 . 0 7}$ \\
\hline Policy delivery & $\mathbf{1 2 . 9 7}$ & 10.92 & $\mathbf{7 . 8 3}$ & 15.72 & $\mathbf{1 5 . 7 5}$ \\
\hline $\begin{array}{l}\text { Political coordination } \\
\text { and State functions }\end{array}$ & $\underline{23.95}$ & $\mathbf{2 9 . 1 6}$ & 11.72 & 18.50 & 23.80 \\
\hline Presidential office & $\underline{30.11}$ & 11.99 & 11.66 & $\mathbf{3 0 . 9 0}$ & 29.88 \\
\hline
\end{tabular}

Source: Elaborated by the authors, based on data provided by Mauerberg Jr. (2016).

Note: The bold values differ with a significance level of $5 \%$ and underlined at $10 \%$. The worst values are in light gray, while the best values are in dark gray. Identical results for post-estimation were obtained using Gabriel and Hochberg's GT2 methods and are indicated in Table 2.

The core area appears to be the most attractive. It reaches first place in four criteria and ties for first in the agreements dimension. Next, we observe the policy delivery units, in second place for four dimensions, except for the agreements. The following two areas are among the least attractive. The ministries charged with political coordination and State functions are tied with units in the presidential office in the last place in relation to the total budget, networking, and patronage, being the least attractive in agreements. The secretariats and smaller ministries in the Presidential office are most attractive only insofar as their capacity to make agreements; however, they are isolated in the dimension of civil servants.

It is worth noting that, despite the prominence of the core area as the most politically attractive, a hierarchy cannot be observed among them. Although the policy delivery units can be classified in the second place, this category does not differ in terms of agreements and civil servants. The last two groups, although clearly less attractive than the first two, are even less distinguishable from each other, as can be seen in the networking and patronage dimension.

Table 3 shows the composition of each area of political attractiveness. The core is occupied by seven ministries: Health, Education, Defense, Justice, Finance, Social Security, and Planning. It differs from other classifications (Mauerberg Jr., 2016; Rennó and Wojcik, 2015), in general, because it includes the Defense, Justice, and, to some extent, Social Security. Contrarily, it is exactly these seven ministries that are among the first placed in the ranking proposed by Batista (2016).

Policy delivery virtually encompasses all ministries responsible for policymaking, with the exception of smaller ministries that are more similar to Presidency secretariats, in line with the findings of Inácio and Llanos (2015) and by Lameirão (2015). The grouping of ministries by criteria of political attractiveness divides the so-called institutional Presidency into two distinct groups. On one side, units responsible for State functions, such as the Attorney General, Comptroller General's Office, Foreign Affairs, and Central Bank, and those charged with political coordination, the case of the Chief of Staff (Casa Civil) and 
the General Secretariat. On the other, the second group includes the departments mainly responsible for policies, including the less attractive ministries, and those in charge of presidential security and the daily political articulation.

\section{Table 3}

\section{Composition of each area of political attractiveness in relation to its ministerial portfolio}

\begin{tabular}{|l|c|c|}
\hline $\begin{array}{l}\text { Areas of political } \\
\text { attractiveness }\end{array}$ & Ministries and secretariats with ministry status & N \\
\hline Core & $\begin{array}{r}\text { Health; Education; Defense; Justice; Finance; Social Security; } \\
\text { and Planning }\end{array}$ & 7 \\
\hline Policy delivery & $\begin{array}{c}\text { Agrarian Development; Environment; Agriculture; Labor; Army; } \\
\text { Air Force; Navy; Interior; Transport; Science, Technology, and } \\
\text { Innovation; Energy; Sport and Tourism; Communications; } \\
\text { Industry, Commerce and Tourism; Development, Industry, and } \\
\text { Foreign Trade; Culture; Cities; and Social Development }\end{array}$ & 18 \\
\hline $\begin{array}{l}\text { Political coordination and } \\
\text { State functions }\end{array}$ & $\begin{array}{c}\text { Attorney General; Comptroller General Office; Foreign Affairs; } \\
\text { Central Bank; Chief of Staff; and the General Secretariat }\end{array}$ & 6 \\
\hline Presidential office* & $\begin{array}{c}\text { Tourism; Sport; Fisheries; Micro and Small Business; Civil } \\
\text { Aviation; Ports; Social Communication; Human Rights; Strategic } \\
\text { Affairs; Institutional Relations; Women; Racial Equality; and } \\
\text { Office of Institutional Security }\end{array}$ & 13 \\
\hline
\end{tabular}

Source: Elaborated by the authors, based on data provided by Mauerberg Jr. (2016).

Note: * Tourism and Sport are the only ministries not allocated in the Presidential office.

Due to this division, it is assumed that the presidents, as principal, tend to exercise the discretionary power over the appointments of their agents in the more politically strategic areas, especially in the core units. In that sense, we expect a balance between politicization and centralization (choosing experts).

To measure level of expertise and politicization of the ministers, we use the index of ministerial politicization (IMP), an indicator initially developed by Borges and Coêlho (2015), with some adjustments. For more details, see the appendix. The index includes variables regarding political performance-linkages with political parties (affiliation and administrative positions inside parties) and experience as an elected official-and technical background-level of education, careers in the public sector, and managerial experience. These variables were organized using publically available information about each of the ministers ${ }^{11}$. The IMP uses a scale of seven (ranging from 0 to 6 ), from the sum of these six binary variables. The lower end (values 0 and 1 ) represents ministers with a

11 The database was mainly based on the biographies gathered by the Center for Research and Documentation of Contemporary History of Brazil (CPDOC) of the Getúlio Vargas Foundation, with complemental data gathered by searching the Internet and referring to historical collections of two Brazilian newspapers: Folha and Estadão. The reference was always the minister's profile at the time of the appointment. 
predominantly technical profile who specialize in policies, while the upper end includes politicians, with strong party ties and political actions (values 5 and 6).

Thus, our first hypothesis is:

H1: Ministerial appointments in the core area are less politicized than in other areas;

The core area covers ministries with big budgets essential to the government framework. Then, it is to be expected that, in addition to the balance between technical and political attributes for the nominations, the Head of the Executive tends to select ministers from his/her own party or candidates with no party affiliation. The preference for the latter is a strategy apparently even more effective in dealing with delegation problems between the president and his own party in a one ruling party system (Martínez-Gallardo and Schleiter 2014). Nonetheless, this may be problematic in regimes within multiparty systems when coalitions are recurrent.

Another way to empirically analyze this likely trade-off is to consider the ideological distance between the president or his party and the coalition's parties. The assumption is identical to the previous one, assuming that in this type of delegation, there is less probability of appointing professionals to these strategic ministries who are ideologically distant from presidents. That said, we present the following hypotheses:

H2.1: The president is more likely to appoint ministers from his or her own party, compared to those without party affiliation or those from allied parties, to ministries in the core area than in other areas of government;

H2.2: The greater the ideological distance between the minister and the president, the lower the probability of being appointed to a ministry in the core area, compared to other areas of government;

Regarding clerks, ministerial appointments of the president's personal quota may be a way of rewarding faithful allies through functions that require a high level of trust. The concept of a president's personal nominations (president's friends) is drawn from Escobar-Lemmon and Taylor-Robinson (2009) and means people of extreme confidence to the head of the executive branch who are publicly known at the time of their appointment.

This group is expected to work closely with the president in ministries that, although less politically attractive than the core area, are central to coordination and advising. It is assumed that the core area will be intensively contested by political parties, and the president is less likely to appoint his or her personal quota to such areas.

H3: Presidents more frequently make personal nominations, appointing ministers more to functions in areas close to the presidency (political coordination, State functions, and the Presidential office) than to functions in the core area.

\section{Empirical analyses}

To test the hypotheses, the present study looks at three presidents and five 
different terms, from 1995 to 2014. We employ the multinomial regression with ratio of relative risks, which is the most appropriate technique when the dependent variable is categorical. There is no hierarchical relationship between the categories of the dependent variable (policy sectors or areas), as expected from the preliminary results already discussed. The tests for applying the multinomial regression model confirm its statistical assumptions. Before discussing the results of the models, we present a descriptive analysis.

\section{Exploratory data analysis}

The variable used to measure political ideology was formulated by Zucco (2014), who uses a sequence of surveys with congressmen and congresswomen to estimate the ideological position of Brazilian political parties over time. The presidents' positions were also estimated, which enables comparisons even to his/her own party, as in previous studies (Martínez-Gallardo and Schleiter, 2014; Wiesehomeier and Benoit, 2009).

To measure the main independent variable, we use the index of ministerial politicization (IMP) described earlier. The intermediate values $(2,3$, and 4$)$ represent the majority $(45 \%)$, the "technical-political" or hybrid profiles, with intermediate levels regarding political insertion and technical performance, although they may vary according to different terms, which is the general assumption.

Based on the IMP, in Figure 2, the darker the slice of the pie chart, the more politicized the appointments. It is noted that the nominations to the core were, on average, less politicized than those made to policy delivery units and to the presidential office. In relation to the political coordination and State functions, this difference is less highlighted, since the latter has a higher concentration of technical profile appointments, the initial stages of the Index of Ministerial Politicization. The core has a greater number of ministers with hybrid or technical-political profiles in comparison to the units of political coordination and State functions, although it has similar values for more politicized appointments at the end of the scale. 
Figure 2

\section{Index of ministerial politicization by areas of political attractiveness}

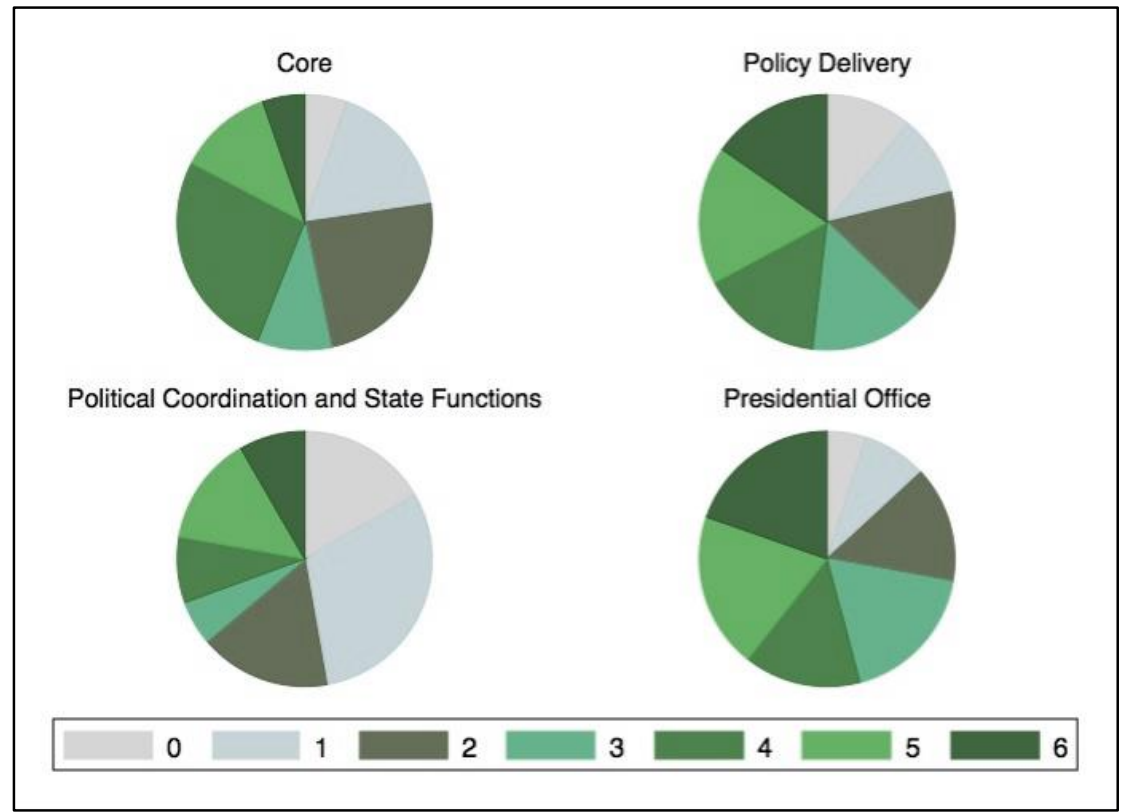

Source: Elaborated by the authors grounded in their own database of cabinet appointments in Brazil (1990 to 2016).

Figure 3 shows differences between government areas, focusing on party affiliation. The core area has a majority of appointments of candidates from the president's party, although there is also a significant presence of non-affiliated candidates and allies, the latter in a smaller proportion than in policy delivery and Presidential office units. Policy delivery is predominantly occupied by ministers from the coalition's parties, while this pattern did not occur in ministries of political coordination and State functions. Finally, the presidency and the smaller departments are equally divided among members of the president's party and allies, leaving just a minor part to ministers with no political affiliations. 
Figure 3

Partisan affiliation by areas of political attractiveness

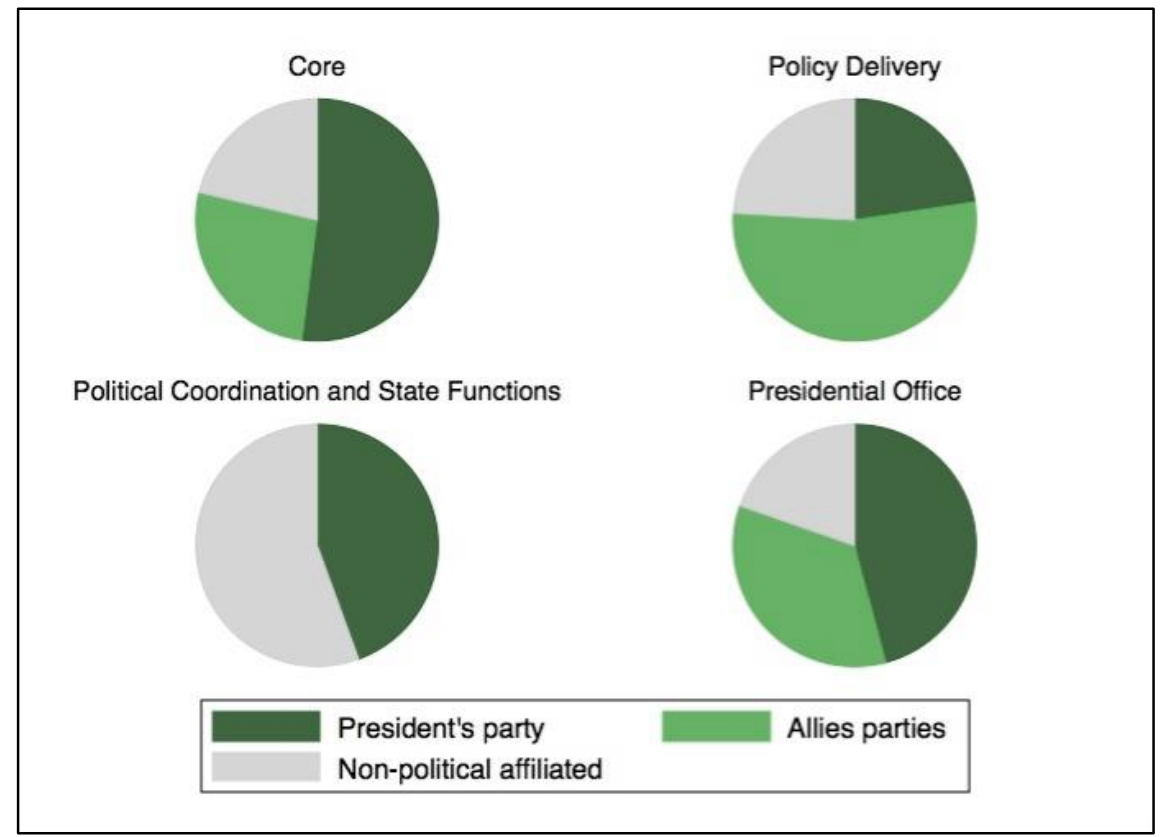

Source: Elaborated by the authors grounded in their own database of cabinet appointments in Brazil (1990 to 2016).

Regarding the president's personal ministerial nominations, Figure 4 depicts the distribution of clerks among the areas. The units responsible for the political coordination and State functions, such as the Chief of Staff and General Secretariat, hold the highest percentage of ministers with close links to the head of the executive branch. The other clusters are quite similar among them; however, the core has a small number of this type of nominations. 


\section{Figure 4}

\section{Relationship with the president by areas of political attractiveness}

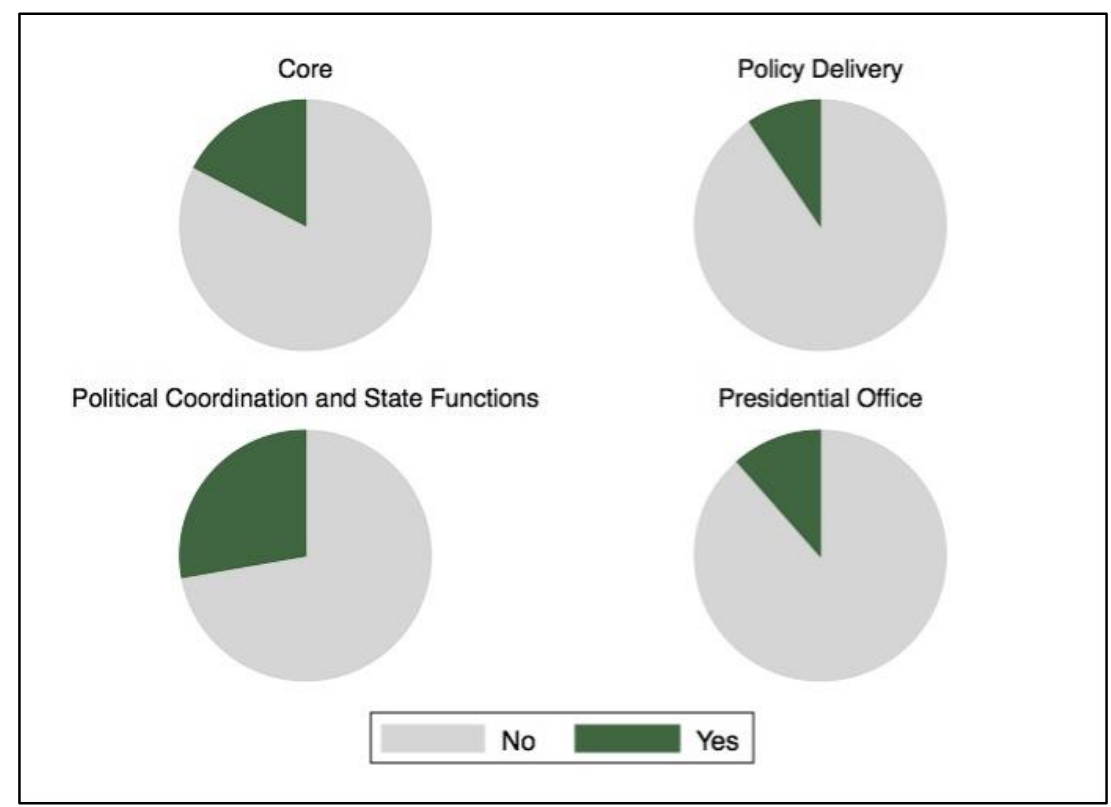

Source: Elaborated by the authors grounded in their own database of cabinet appointments in Brazil (1990 to 2016).

In general, there are nontrivial distinctions among government areas, according to their greater or lesser political desirability. This fact tends to confirm the basic hypothesis of the literature that the president does not appoint collaborators merely considering a rewards metric and parties' proportionality in the parliament. The president's concern also involves constraints and needs for the better functioning of government, choosing to define ex ante what type of agent will occupy positions in the cabinet. Moreover, as we will discuss further, it is common for the president to set apart the most attractive ministries, which can be seen as resistance to yielding important spaces of power to the coalition.

\section{Results of the models}

Table 4 presents the results of applied multinomial logistic regressions in order to test and discuss the paper's hypotheses. The three models show the estimates using the core area as the category of comparison, which supposedly holds ministries with the highest attributes of political attractiveness in relation to the other three areas. 
Table 4

Determinants of ministerial appointments in the core area compared to the other areas

\begin{tabular}{|c|c|c|c|c|}
\hline \multicolumn{2}{|l|}{ Variables } & Delivery vs. Core (1) & $\begin{array}{c}\text { Political coordination } \\
\text { and state functions vs. } \\
\text { Core (2) }\end{array}$ & $\begin{array}{c}\text { Presidential office } \\
\text { vs. Core (3) }\end{array}$ \\
\hline \multicolumn{2}{|c|}{$\begin{array}{l}\text { Index of Ministerial } \\
\text { Politicization }\end{array}$} & $\begin{array}{c}1.233 \\
(0.145)^{*}\end{array}$ & $\begin{array}{c}1.231 \\
(0.230)\end{array}$ & $\begin{array}{c}1.538 \\
(0.222)^{* * *}\end{array}$ \\
\hline $\begin{array}{l}\text { Party } \\
\text { affiliation }\end{array}$ & $\begin{array}{l}\text { No party } \\
\text { affiliation }\end{array}$ & $\begin{array}{c}4.942 \\
(2.769)^{* * *}\end{array}$ & $\begin{array}{c}12.172 \\
(12.585)^{* *}\end{array}$ & $\begin{array}{c}4.130 \\
(2.803)^{* *}\end{array}$ \\
\hline \multicolumn{2}{|c|}{ Allied parties } & $\begin{array}{c}4.273 \\
(2.402)^{* * *} \\
\end{array}$ & $\begin{array}{c}0.000 \\
(0.000) \\
\end{array}$ & $\begin{array}{c}1.036 \\
(0.726) \\
\end{array}$ \\
\hline \multicolumn{2}{|l|}{ Woman } & $\begin{array}{c}8.991 \\
(9.942)^{* *}\end{array}$ & $\begin{array}{l}3.471 \\
(4.27)\end{array}$ & $\begin{array}{c}25.049 \\
(27.940) * * *\end{array}$ \\
\hline \multicolumn{2}{|l|}{ Black } & $\begin{array}{c}7.011 \\
(7.596) *\end{array}$ & $\begin{array}{c}0.000 \\
(0.002)\end{array}$ & $\begin{array}{c}17.565 \\
(19.426)^{* * *}\end{array}$ \\
\hline \multicolumn{2}{|l|}{ Age } & $\begin{array}{c}1.006 \\
(0.019) \\
\end{array}$ & $\begin{array}{c}1.014 \\
(0.028) \\
\end{array}$ & $\begin{array}{c}1.010 \\
(0.024) \\
\end{array}$ \\
\hline \multicolumn{2}{|l|}{ São Paulo } & $\begin{array}{c}0.327 \\
(0.137)^{* * *}\end{array}$ & $\begin{array}{c}0.137 \\
(0.084)^{* * *}\end{array}$ & $\begin{array}{l}0.546 \\
(0.263)\end{array}$ \\
\hline \multicolumn{2}{|c|}{$\begin{array}{l}\text { Family member of a } \\
\text { politician(s) }\end{array}$} & $\begin{array}{c}0.831 \\
(0.438)\end{array}$ & $\begin{array}{l}2.695 \\
(1.95)\end{array}$ & $\begin{array}{l}0.566 \\
(0.398)\end{array}$ \\
\hline \multicolumn{2}{|c|}{$\begin{array}{l}\text { Personal nomination } \\
\text { (president's friends) }\end{array}$} & $\begin{array}{c}1.480 \\
(0.834)\end{array}$ & $\begin{array}{c}6.481 \\
(4.695)^{* * *}\end{array}$ & $\begin{array}{c}0.658 \\
(0.443)\end{array}$ \\
\hline \multicolumn{2}{|c|}{ Ministerial clientele } & $\begin{array}{l}1.979 \\
(0.957)\end{array}$ & $\begin{array}{c}0.342 \\
(0.279)\end{array}$ & $\begin{array}{c}0.748 \\
(0.468)\end{array}$ \\
\hline \multicolumn{2}{|c|}{ Ideological difference } & $\begin{array}{c}0.966 \\
(0.291)\end{array}$ & $\begin{array}{l}10.004 \\
(22.22)\end{array}$ & $\begin{array}{c}1.119 \\
(0.442)\end{array}$ \\
\hline \multicolumn{2}{|l|}{ Constant } & $\begin{array}{c}0.265 \\
(0.306)\end{array}$ & $\begin{array}{c}0.051 \\
(0.098)\end{array}$ & $\begin{array}{c}0.067 \\
(0.094) *\end{array}$ \\
\hline \multicolumn{2}{|l|}{$N$} & 305 & 305 & 305 \\
\hline \multicolumn{2}{|l|}{ LR chi2 } & 143.39 & 143.39 & 143.39 \\
\hline \multicolumn{2}{|c|}{ Prob > chi2 } & 0.00 & 0.00 & 0.00 \\
\hline \multicolumn{2}{|c|}{ Pseudo $\mathrm{R}^{2}$} & 0.18 & 0.18 & 0.18 \\
\hline
\end{tabular}

Source: Elaborated by the authors.

Note: $* \mathrm{p}<0.1 ; * * \mathrm{p}<0.05 ; * * * \mathrm{p}<0.01$. Standard error in parentheses.

The empirical results are quite interesting from many perspectives. First, the increase of one digit in the index of ministerial politicization tends, on average, to increase the chances of appointments in policy delivery of $25 \%$ and $50 \%$ in the presidential office compared with the core, keeping all other factors constant. The political coordination and State functions did not show statistically significant differences, as identified in the previous descriptive analysis. In this area, the high percentage of nominees of non-party affiliated ministers prevails, i.e., representing less politicization in ministerial appointments.

Regarding the party dimension, non-affiliated ministers, compared to those from the president's party, are more likely to be appointed to all other areas than to the core. Ministers from allied parties, compared to those from the president's party, have higher chances of being appointed to the policy delivery units. Model 3 doesn't present statistically significant differences, while in the political coordination and State functions no 
appointments occurred in the period analyzed. Therefore, although there are appointments of non-party affiliated ministers and ministers from allied parties, the president's personal nominations tend to be more recurrent in the politically key areas of government than in clusters. These results are consistent across all models presented. In all models, the estimates are consistent and statistically significant.

With regards to demographic variables, it is evident that women and people who identify as Black are more frequently nominated to policy delivery units and to the presidency, compared to the core. Besides, no black ministers were appointed during the entire period of this study in political coordination and State function ministries. Thus, as expected due to the average profile of ministers in Brazil, the appointment of Black and female candidates is less frequent in the most politically attractive ministries. Candidates from the country's richest state, São Paulo, are also less likely to be appointed to policy delivery ministries and political coordination and State functions than to the core compared to candidates from other states. There was no statistically significant difference between the proportion of ministers from São Paulo appointed to the presidential office in relation to the core area.

Regarding the three variables of political linkages, only presidential nominations (president's friends) shows a statistically significant estimate. Its coefficient means that the president's friends are five to six times more likely to be appointed to the political coordination and State functions clusters than to the more politically attractive ministries. The other coefficients do not present any statistically significant effects. Lastly, the ideological distance between the president and his or her ministers is not relevant as well, once controlled by the type of party affiliation ${ }^{12}$.

The Figure 5 addresses the predicted probability of ministerial appointments according to the index of ministerial politicization. It is noticeable a declining line in which the greater the politicization of ministers, the less likely they are to be appointed in the core cluster.

\footnotetext{
12 When we removed this variable, ideology was statistically significant only in one comparison. The greater the ideological distance, the lower the likelihood of nomination to a position of political coordination compared to the core. That is, the core was more receptive to ministers with greater ideological distance from the president compared to ministries that perform state functions and political coordination.
} 


\section{Figure 5 \\ Effect of the index of ministerial politicization on the probability of ministerial appointment to the core}

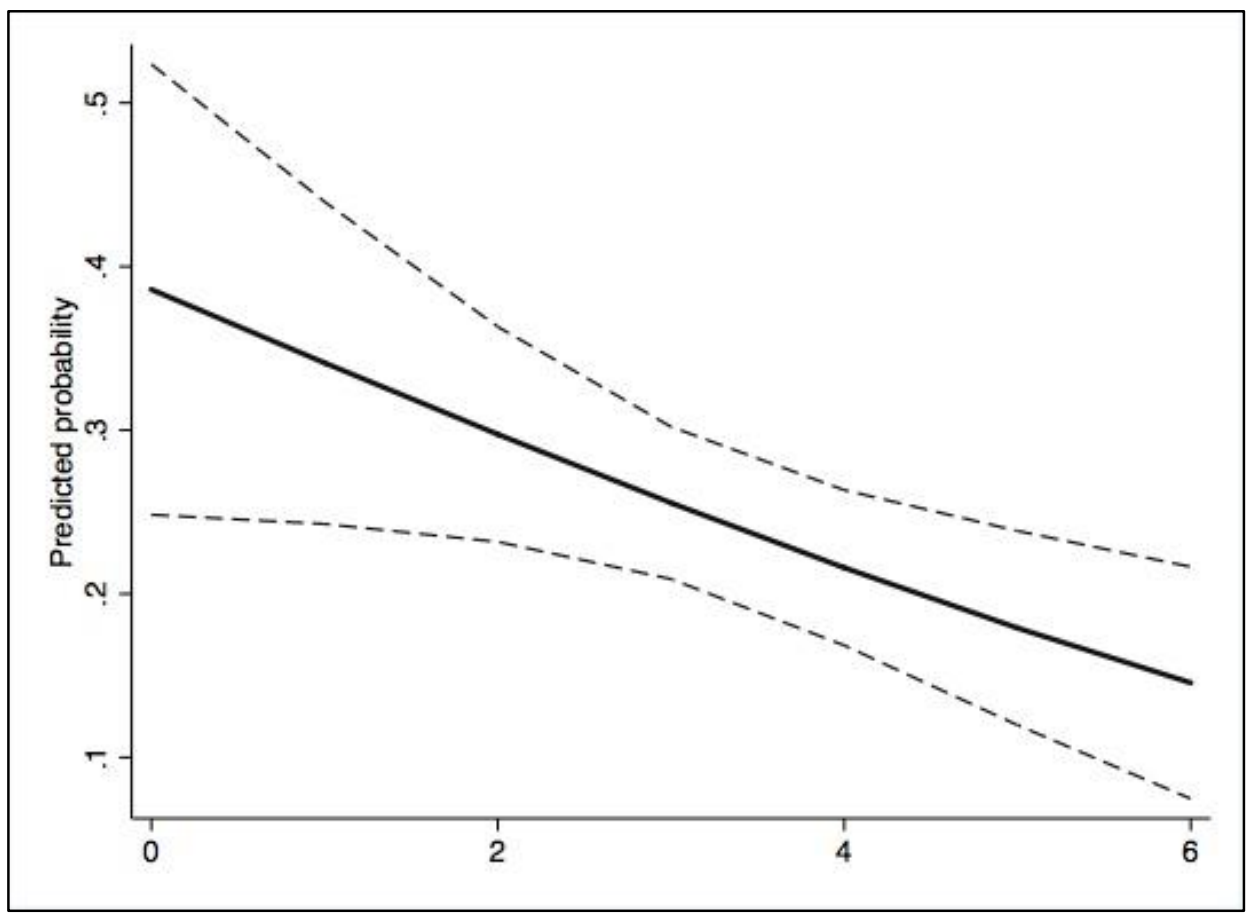

Source: Elaborated by the authors grounded in their own database of cabinet appointments in Brazil (1990 to 2016).

\section{Discussion and conclusions}

The qualitative dimensions of cabinet appointment is a topic first explored in studies of parliamentary systems that draw attention to the functioning of coalitions in presidentialist contexts. The challenges presented by this research strategy are mainly methodological: how can we measure each ministry's salience in order to better understand its distribution in the governing coalition?

In this vein, the research proposed a measure for groups of ministries based on their political attractiveness, which differs from the recurring method focused on the coalescence rate.

Besides exploratory analysis with an original dataset, the paper also advances other empirical tests. As a result, the first hypothesis of less politicization in the government core was confirmed, considering the IMP as proxy of politicization. The delivery units and the Presidency are, on average, more politicized than the former. The exception comes from the units responsible for the political coordination and State functions, which do not differ statistically from the core area. The presidents have chosen to politicize with less intensity the ministries most central to the government, appointing candidates with 
hybrid profiles, with some technical specialization, and political experience. Thus, not only are the ministries different in their attractiveness, but also presidents vary in the way they appoint their agents. It is clear that regarding the core, in a certain way, presidents tend to shield these ministries from politicization.

Hypothesis 2.1 is confirmed by the statistical models as well. As expected, ministers from the president's party are more likely to be appointed to the core areas, although there are also the coalition allies and non-party affiliated candidates in that area. There is no evidence to confirm hypothesis 2.2 .

The third hypothesis refers to the president's personal nominations; it is partially confirmed by the empirical tests. While it is true that these appointments took place for the most part in the presidency, there was a predominance of some attributions over others. The personal nominations were greater in the presidency units that carry out political coordination and other important functions of the State. This difference, however, did not prove to be significant for presidential secretariats and ministries of minor political importance.

Another interesting finding involves the gender and race dimensions. As a rule, these minorities are further away from the more central ministries. This is well knowncommon sense-in the literature (D'Araujo and Lameirão, 2009; D'Araujo, 2014). Despite the fact that in the last decade there has been a considerable increase of female and Black candidates occupying the top positions in government, this expansion was not followed by the occupation of more relevant decision-making posts. In the period from 1995 to 2014, there was only one appointment of a woman to the most politically attractive unit, the Ministry of Planning, and only a single appointment of a Black minister, to the Ministry of Education. Both took place during Dilma Rousseff's first government.

In terms of the regional aspect, the most attractive ministries are more likely to receive ministers whose professional backgrounds are directly linked to São Paulo. This is yet another element to be added to Figueiredo's (2007) thesis on the federative imbalance in the Brazilian cabinet allocation. The ministers from São Paulo-born in the state or immigrated-are disproportionately appointed (in general) to the most politically attractive units.

In this sense, it is evident that the pattern of cabinet appointments in Brazil is quite different from that of parliamentary systems and even among presidentialist countries. Coalition management has become increasingly relevant to understanding how multiparty governments achieve their strategic agenda and even survive during tenure. To do so, the head of the executive branch must handle the distribution of power among his or her partners. The empirical knowledge provided by this research, which uses different analytical methods to analyze an original and current database of ministerial appointments in a young democratic political system such as Brazil, adds insights into this interesting but still underdeveloped field of study.

Therefore, areas of future research can be rather broad. One prominent subject 
involves the occurrence of mergers or divisions as part of the presidents' strategy to manage costs and benefits in coordinating coalitions, with consequences for their ministers' political attractiveness. Other evidence that may be better explored is related to the institutional Presidency or to studies of the Center of Government. The distinction made here between clusters of ministries divides the unit of the presidency into two distinct areas. It seems that in order to understand the complex functioning of ministries and advisory units close to the president, one must consider different dynamics and power relationships. Although the nominations of politicians from allied parties is less frequent, in general, there are some interesting cases in the period analyzed. Investigating their causes and consequences, probably based on qualitative case studies, is also an interesting way to better understand how the executive branch operates.

Another important issue is related to how to distinguish between ministries. Warwick and Druckman $(2001,2006)$ discuss the limitations of many approaches designed to measure the ministry's salience. For them, some designs give room for greater subjectivity, such as those centered on expert surveys, others leave important dimensions aside, such as those based on objective indicators. There still exist some difficulties in incorporating political parties' and the president's preferences. For instance, labor parties and environmentalists tend to be more in tune with welfare and sustainability. However, conservative parties tend to be more willing to command ministries related to economics (Dowding and Dumont, 2009). This interest in specific portfolios may even be in line with the occupation of similar offices at the subnational level.

Presidents often highlight their priorities and preferences in their speeches during their electoral campaigns or upon inauguration, as well as in their annual messages to Congress, which can be investigated from a comparative perspective (Hollibaugh Jr., Horton and Lewis, 2014). Presidents are also elected by direct delegation by the population, and they have different agendas compared to parliamentary representation. Their constituencies, for that reason, are nationwide. In addition, they are accountable for specific areas of public policy, such as the economy, and have autonomy in deciding their cabinet formation. These elements seem to support the proposition that certain ministries, those most relevant to the president, tend to be more rigorously delegated and monitored. It is also assumed that on such occasions the weight given to certain ministerial agendas and units may change between and even during administrations, which can significantly impact their degree of salience.

\section{Bibliographic references}

Abranches, S. "Presidencialismo de coalizão: o dilema institucional brasileiro". Dados, vol. 31, no 1, p. 5-34, 1988.

Abrucio, F. L.; CostA, V. M. F. Reforma do estado e o contexto federativo brasileiro. São Paulo: Fundação Konrad-Adenauer-Stiftung, 1999. 
ALTMAN, D. "The politics of coalition formation and survival in multiparty presidential democracies: the case of Uruguay, 1989-1999". Party Politics, vol. 6, no 3, p. 259-283, 2000.

Amorim Neto, O. "Gabinetes presidenciais, ciclos eleitorais e disciplina legislativa no Brasil". Dados, vol. $43, n^{\circ} 3,2000$.

. "O Poder Executivo, centro de gravidade do sistema político brasileiro". In: AVELAR, L.; CINTRA, A. O. (orgs.). Sistema político brasileiro: uma introdução. $2^{a}$ ed. rev. e ampl. Rio de Janeiro: Fundação Konrad Adenauer, 2007.

AMORIM Neto, O.; SAMUels, D. "Democratic regimes and cabinet politics: a global perspective". Revista Ibero-Americana de Estudos Legislativos, vol. 1, n 1, 2010.

ARRETCHE, M. "Continuidades e descontinuidades da federação brasileira: de como 1988 facilitou 1995". Dados, vol. 52, no 2, p. 377-423, 2009.

BARBERIA, L.; PRAÇA, S. "Who gets political appointments? Party loyalty and bureaucratic expertise in Brazil". Annals of the Midwestern Political Science Association Meeting, Chicago, 2014.

BATISTA, M. "O mistério dos ministérios: a governança da coalizão no presidencialismo brasileiro". Tese de Doutorado. Departamento de Ciência Política. Universidade Federal de Pernambuco (UFPE), Recife, 2014.

. "Quem ganha o quê e como isso importa? Alocação de ministérios e apoio legislativo no Brasil". 100 Encontro da Associação Brasileira de Ciência Política (ABCP), Belo Horizonte, 2016.

BERLINSKI, S., et al. Choosing, moving and resigning at Westminster. In: DowDING, K.; DUMONT, P. (eds.). The selection of ministers in Europe: hiring and firing (Routledge advances in European politics, 52). London: Routledge - Taylor \& Francis Group, 2009.

BORGES, A.; COÊLHO, D. O preenchimento de cargos da burocracia pública federal no presidencialismo de coalizão brasileiro: análise comparativa de dois ministérios - Ciência e Tecnologia e Integração Nacional. In: LOPEZ, F. G. Cargos de confiança no presidencialismo de coalizão brasileiro. Brasília: Ipea, 2015.

Cavalcante, P.; Camões, M. R. S.; KnOPP, M. Burocracia de médio escalão nos setores governamentais: semelhanças e diferenças. In: CAVALCANTE, P.; LOTTA, G. (orgs.). Burocracia de médio escalão: perfil, trajetória e atuação. Brasília: Escola Nacional de Administração Pública (Enap), 2015.

Cavalcante, P.; Carvalho, P. "Profissionalização da burocracia federal brasileira (1995-2014): avanços e dilemas". Revista de Administração Pública, vol. 51, n 1, 2017.

D'Araujo, M. C. Elites burocráticas, dirigentes públicos e política no Poder Executivo. In: D'ARAUjo, M. C. (org.). Redemocratização e mudança social no Brasil. Rio de Janeiro: Editora da FGV, 2014.

D'Araujo, M. C.; LAmeirão, C. A elite dirigente do governo Lula. Rio de Janeiro: Centro de Pesquisa e Documentação de História Contemporânea do Brasil (CPDOC)/Fundação Getúlio Vargas (FGV), 2009.

DIXIT, A "Power of incentives in private versus public organizations". The American Economic Review, vol. 87, $\mathrm{n}^{\circ}$ 2. Papers and Proceedings of the Hundred and Fourth Annual Meeting of the American Economic Association, 1997.

DOWDING, K.; DUMONT, P. Structural and strategic factors affecting the hiring and firing of ministers. In: DowDING, K.; DUMONT, P. (eds.). The selection of ministers in Europe: hiring and firing (Routledge advances in European politics, 52). London: Routledge - Taylor \& Francis Group, 2009.

ESCOBAR-LEMmON, M.; TAYLOR-ROBInSON, M. M. "Do cabinet ministers in presidential systems have experience in their portfolio or is on-the-job training the norm?". International Political Science 
Association Meeting, Santiago, Chile, 2009.

FÁvero, L. P.; BefIORE, P. Análise de dados: técnicas multivariadas exploratórias com SPSS $R$ e Stata ${ }^{\circledR}$. Rio de Janeiro: Elsevier, 2015.

Figueiredo, A. "Coalition government in the Brazilian democracy". Brazilian Political Science Review, vol. 1, no 2, 2007.

Figueiredo, A.; Canello, J.; Vieira, M. "Governos minoritários e presidencialismo latino-americano". Dados, vol. 55, no 4, p. 839-875, 2012.

Figueiredo, A.; Limongi, F. Executivo e Legislativo na nova ordem constitucional. Rio de Janeiro: Editora da FGV/Fapesp, 1999.

Instituições políticas e governabilidade: desempenho do governo e apoio legislativo na democracia brasileira. In: RANULFO, C.; SÁEZ, M. A. (orgs.). A democracia brasileira: balanço e perspectivas para o século 21. Belo Horizonte: Editora da UFMG, 2007.

FloRES, A. Q. United States of America: the cabinet. In: Dowding, K.; DumonT, P. (eds.). The selection of ministers around the world (Routledge research on social and political elites, 5). London: Routledge - Taylor \& Francis Group, 2015.

FRANZ JR., P.; CODATO, A. "O recrutamento ministerial no Brasil: trajetória profissional e filiação partidária de FHC a Lula". Anais do VII Seminário Nacional Sociologia \& Política. Curitiba, 2016.

Hollibaugh JR., G. E.; HoRton, G.; Lewis, D. E. "Presidents and patronage". American Journal of Political Science, vol. 58, no 4, 2014.

INÁcıo, M. "Escogiendo ministros y formando politicos: los partidos en gabinetes multipartidistas". América Latina Hoy, vol. 64, 2013.

INÁCIO, M.; LLANOS, M. "The institutional presidency from a comparative perspective: Argentina and Brazil since the 1980s". Brazilian Political Science Review, vol. 9, no 1, 2015.

LAMEIRÃo, C. R. Os níveis de controle da presidência sobre a coordenação política governamental e a coalizão partidária (1995-2010). In: LOPEZ, F. G. (org.). Cargos de confiança no presidencialismo de coalizão brasileiro. Brasília: Ipea, 2015.

LEWIS, D. E. "Revisiting the administrative presidency: policy, patronage, and agency competence". Presidential Studies Quarterly, vol. 39, no 1, 2009.

Limongi, F.; Figueiredo, A. Poder de agenda e políticas substantivas. In: InÁcio, M.; RenNó, L. (orgs.). Legislativo brasileiro em perspectiva comparada. Belo Horizonte: UFMG, 2009.

MAChADO, J. A.; PALOtTI, P. L. M. "Entre cooperação e centralização: federalismo e políticas sociais no Brasil pós-1988". Revista Brasileira de Ciências Sociais, vol. 30, 2015.

MARTínez-Gallardo, C.; SChleiter, P. "Choosing whom to trust: agency risks and cabinet partisanship in presidential democracies". Comparative Political Studies, vol. 4, 2014.

MAUerberg JR., A. "Cabinet composition and assessment of a multiparty presidential system". Tese de Doutorado. Escola de Administração de Empresas de São Paulo da Fundação Getúlio Vargas, São Paulo, 2016.

Meneguello, R. "Partidos e governos no Brasil contemporâneo (1985-1995)". Tese de Doutorado. Instituto de Filosofia e Ciências Humanas, Universidade Estadual de Campinas, Campinas, 1996.

NIKOLENYI, C. India: the selection and de-selection of cabinet ministers. In: DoWDING, K.; DUMONT, P. 
(eds.). The selection of ministers around the world (Routledge research on social and political elites, 5). London: Routledge - Taylor \& Francis Group, 2015.

NiSKANEN, W. Bureaucracy and public economics. Cheltenham: Edward Elgar Publishing, 1994 [1971].

Nunes, F. "Os determinantes dos resultados de soma positiva em Minas Gerais e no Rio Grande do Sul". Revista de Sociologia e Política, vol. 21, no 47, 2013.

PALOTTI, P. "Estratégias de seleção e substituição de ministros de Estado no presidencialismo de coalizão brasileiro: perfil, alocação e rotatividade". Tese de Doutorado, Instituto de Ciência Política, Universidade de Brasília, Brasília, 2017.

PereirA, C., et al. "Top managers and risk of policy expropriation in multiparty presidential regimes". International workshop on Coalition Management in Multiparty Presidentialism in Comparative Perspective, Ebape/FGV, 2013.

. A nomeação de secretários-executivos e o monitoramento da coalizão no presidencialismo brasileiro. In: LOPEZ, F. G. Cargos de confiança no presidencialismo de coalizão brasileiro. Brasília: Ipea, 2015.

Pereira, C.; Bertholini, F.; Raile, E. D. "All the president's men and women: coalition management strategies and governing costs in a multiparty presidency". Presidential Studies Quarterly, vol. 46, $\mathrm{n}^{\circ}$ 3, 2016.

RenNó, L.; WoJCIK, S. "The changing role of ministers in the legislative agenda in Brazil". Revista Iberoamericana de Estudos Legislativos, vol. 4, no 1, 2015.

Ross, S. A. "The economic theory of agency: the principal's problem". American Economic Review, vol. 63, n², 1973.

VERZICHELLI, L. "Italy: the difficult road towards a more effective process of ministerial selection". In: DoWding, K.; DUMONT, P. (eds.). The selection of ministers in Europe: hiring and firing (Routledge advances in European politics, 52). London: Routledge - Taylor \& Francis Group, 2009.

WARWICK, P. V.; DRUCKMAN, J. N. "Portfolio salience and proportionality of payoffs in coalition governments". British Journal of Political Science, vol. 31, 2001.

"The portfolio allocation paradox: an investigation into the nature of a very strong but puzzling relationship". European Journal of Political Research, vol. 45, n 4, 2006.

Wiesehomeier, N.; Benoit, K. "Presidents, parties, and policy competition". The Journal of Politics, vol. 71, n० 4, 2009.

Zucco, C. "The new meaning of left and right in Brazil: an analysis of the ideology of political elites since redemocratization". Encontro da Associação Brasileira de Ciência Política (ABCP), Brasília, 2014.

\section{Appendix}

Ministerial politicization index (MPI)

The IPM proposal is an unfolding of the ministerial partisanization index presented by Borges and Coêlho (2015). Its scale has seven points, from 0 to 6 , generating the direct sum of six binary variables. 
a) Party affiliation: being affiliated to a political party when appointed Minister; (Yes - 1 point)

b) Elective position: having been elected to any office (in the executive or legislative branches, at any level of government) prior to appointment to the position of minister; (Yes - 1 point)

c) Position in party administration: having held a position in the administrative structure of the political party (national presidency, state or municipal presidency, general secretary, treasury etc., including in its foundation); (Yes - 1 point)

d) Academic training: holding an academic degree at a master's or doctoral level; (No - 1 point)

e) Public or military servants: have previously pursued a career in the military or as a public servant; (No - 1 point)

f) Management experience in the area: having held managerial positions directly related to the post of minister occupied, at the national or subnational level; (No - 1 point)

The Cronbach's Alpha of MPI is 0.749 . It is above the parameter of 0.70 , considered as the minimum threshold to indicate the existence of unidimensionality in the observed factor (Hair Jr. et al. 2014). For further details about the MPI elaboration, see Palotti (2017).

\section{Division of ministries through cluster analysis}

Cluster analysis is an exploratory statistical technique used with the objective of dividing the observations into distinct groups according to the existence of similar behaviors. In this way, it is desired to allocate the observations in "homogeneous groups internally and heterogeneous between themselves" (Fávero and Belfiore, 2015).

The division of ministries into different areas of political attractiveness adopted the following variables, collected by Mauerberg Jr. (2016): a) total budget; b) voluntary transfers; c) networking; d) civil servants; and e) patronage. His research presents the ranking of ministries for each of these dimensions, year by year. For the purpose of this study, the average position of each ministry was calculated for each dimension, totaling 47 ministries, three of which were excluded because they did not have data for at least one of the variables (in the case of the ministries of the Federal Administration and State Reform, Social Welfare, and Regional Integration).

Determining the number of clusters is not a simple task and, as for other definitions in statistics, must take into account the research objectives and the adopted theory (Fávero and Belfiore, 2015). Based on this, the solution with four clusters was chosen, which is the second major jump, similar to the solution with five clusters, with the advantage of not differentiating in an isolated cluster the Ministries of Planning and Social Security. There are theoretical reasons to insert them into a core cluster (Rennó and Wojcik, 2015; Pereira et al., 2013). The solution with three clusters, besides not being visible in the dendogram, results in a smaller jump than the previous options.

Figure 6 illustrates the dendogram using cluster analysis with the standards described before. For further details about this technique, see Palotti (2017). 
Figure 6

Dendogram using complete linkage

\begin{tabular}{|c|c|c|c|c|c|}
\hline & $\begin{array}{l}5 \\
1\end{array}$ & $\stackrel{10}{1}$ & $\underset{15}{15}$ & $\begin{array}{c}20 \\
1\end{array}$ & $\stackrel{25}{1}$ \\
\hline \multicolumn{6}{|c|}{ Secretaria de Polticas de Promoçăo da lgualdade Racial } \\
\hline \multicolumn{6}{|c|}{ Secretaria de Pollicas para as Mulheres } \\
\hline \multicolumn{6}{|c|}{ Secretaria de Relaçōes Institucionais } \\
\hline \multicolumn{6}{|c|}{ Secretaria de Assuntos Estratégicos } \\
\hline \multicolumn{6}{|c|}{ Gabinete de Segurança Institucional } \\
\hline \multicolumn{6}{|c|}{ Ministério da Pesca e Aquicultura } \\
\hline \multicolumn{6}{|c|}{ Secretaria de Direttos Humanos } \\
\hline \multicolumn{6}{|c|}{ Secretaria de Comunicação Social } \\
\hline \multicolumn{6}{|l|}{ Secretaria de Portos } \\
\hline \multicolumn{6}{|l|}{ Ministério do Esporte } \\
\hline \multicolumn{6}{|l|}{ Ministério do Turismo } \\
\hline \multicolumn{6}{|c|}{ Secretaria de Aviaçāo Civi } \\
\hline \multicolumn{6}{|c|}{ Secretaria da Mcro e Pequena Empresa } \\
\hline \multicolumn{6}{|l|}{ Banco Central } \\
\hline \multicolumn{6}{|c|}{ Secretaria-Geral da Presidência } \\
\hline \multicolumn{6}{|l|}{ Casa Civi } \\
\hline \multicolumn{6}{|c|}{ Controladoria-Geral da Uni5̄o } \\
\hline \multicolumn{6}{|l|}{ Advogado-Geral da Uniāo } \\
\hline \multicolumn{6}{|c|}{ Mnistério das Relaçס̄es Exteriores } \\
\hline \multicolumn{6}{|c|}{ Ministério do Desenvolvimento Social e Combate à Fome } \\
\hline \multicolumn{6}{|l|}{ Ministério das Cidades } \\
\hline \multicolumn{6}{|l|}{ Mnistério da Cutura } \\
\hline \multicolumn{6}{|c|}{$\begin{array}{l}\text { Ministério do Desenvolvimento, Indústria e Comércio } \\
\text { Exterior }\end{array}$} \\
\hline \multicolumn{6}{|c|}{ Mnistério da indústria, Comércio e Turismo } \\
\hline Ministério das Comunic: & & & & & \\
\hline Ministério do Esporte e & & & & & \\
\hline Ministério das Minas e E & & & & & \\
\hline Ministério da Clência, T & & & & & \\
\hline Ministério dos Transpor & & & & & \\
\hline Ministério da integraçä́c & & & & & \\
\hline Marinha & & & & & \\
\hline Força Aérea & & & & & \\
\hline Exército & & & & & \\
\hline Ministério do Trabalho e & & & & . & \\
\hline Ministério da Agricutur: & & & & & \\
\hline Ministério do Meio Ambi & & & & & \\
\hline Ministério do Desenvoh & & & & & \\
\hline Ministério do Planejame & & & & & \\
\hline Mnistério da Previdênc & & & & & \\
\hline Ministério da Fazenda & & & & & \\
\hline Ministério da Justiça & & & & & \\
\hline Ministério da Defesa & & & & & \\
\hline Ministério da Educaçăo & & & & & \\
\hline Ministério da Saúde & & & & & \\
\hline
\end{tabular}

Source: Elaborated by the authors, grounded in data provided by Mauerberg Jr. (2016). 


\section{Resumo}

Há uma solução única para tudo? Uma análise da alocação dos ministérios no presidencialismo multipartidário brasileiro

Os presidentes enfrentam um dilema de quem nomear para cargos no gabinete. Eles precisam produzir apoio legislativo para seu governo ao mesmo tempo que alcançam seus objetivos em termos de políticas públicas. O artigo analisa a alocação de portfólio escolhida pelos presidentes brasileiros em um sistema multipartidário. O estudo testa algumas hipóteses utilizando uma regressão logística multinomial para identificar as estratégias de nomeação adotadas pelos presidentes em quatro setores governamentais diferentes de 1990 a 2016. Para tanto, nós criamos o índice de politização ministerial e agregamos os ministérios nesses quatro setores, empregando análise de clusters. Os resultados mostram que as indicações no núcleo do governo tendem a ser menos politizadas. Ademais, as nomeações pessoais do presidente foram maiores nas unidades da presidência que realizam a coordenação política e as funções típicas do Estado.

Palavras-chave: sistema presidencial multipartidário; nomeação de ministros; gestão de coalizão governamental; Brasil

\section{Resumen}

¿Hay una solución única para todo? Un análisis de la asignación ministerial en el presidencialismo multipartidista brasileño

Los presidentes se enfrentan a un dilema sobre a quién designar para cargos en el gabinete. Necesitan generar el apoyo legislativo para su gobierno al mismo tiempo que logran los objetivos de política pública. El estudio analiza algunas hipótesis utilizando una regresión logística multinomial para identificar las estrategias de nombramiento adoptadas por los presidentes en cuatro sectores gubernamentales diferentes de 1990 a 2016. En primer lugar, creamos un índice ministerial de politización (IMP) y agregamos los ministerios en estas cuatro secciones, empleando cluster analysis. Los resultados muestran que el nombramiento en el centro del gobierno tiende a ser menos politizado. Además, las nominaciones personales del presidente son mayores en las unidades de la Presidencia que es responsable por la coordinación de política pública y por las funciones típicas del Estado.

Palabras-clave: sistema presidencial multipartidista; nombramiento de ministros; administración de la coalición del gobierno; Brasil

\section{Résumé}

Y a-t-il une solution unique pour tout? Une analyse de l'attribution ministérielle dans le multipartisme présidentiel brésilien

Les présidents sont confrontés à un dilemme quant aux personnes à nommer pour les postes ministériels. Ils doivent apporter un soutien législatif à leur gouvernement tout en atteignant les objectifs de politique publique. L'étude analyse certaines hypothèses en utilisant une régression logistique multinomiale pour identifier les stratégies de dénomination adoptées par les présidents dans quatre secteurs gouvernementaux différents de 1990 à 2016. Pour ce faire, nous créons d'abord un index de la politique ministérielle (IMP) et regroupons les ministères dans ces quatre sections, en utilisant l'analyse en cluster. Les résultats montrent que les nominations au sein du gouvernement ont tendance à être moins politisées. En outre, les nominations personnelles du président sont plus importantes dans les unités présidentielles qui sont responsables de la coordination de politique publique et des fonctions typiques de l'État.

Mots-clés: système présidentiel multipartite; nomination des ministres; gestion de la coalition gouvernementale; Brésil

Artigo submetido à publicação em 24 de fevereiro de 2018. Versão final aprovada em 12 de julho de 2018.

Opinião Pública adota a licença Creative Commons CC-BY. 